\title{
Application of Risk-Adjusted Returnon Capital (RAROC) in Measuring the Effects of Macroprudential Policy on Sharia Bank Market Risks in Indonesia
}

\author{
Aqidah Asri Suwarsi ${ }^{1, *}$ Safaah Restuning Hayati ${ }^{2}$ Setiawan Aji ${ }^{3}$
}

\author{
${ }^{I}$ Department of Sharia Economic, Universitas Muhammadiyah Yogyakarta \\ ${ }^{2}$ Department of Sharia Economic, Universitas Muhammadiyah Yogyakarta \\ ${ }^{3}$ Department of Sharia Economic, Universitas Muhammadiyah Yogyakarta \\ "Email: aqidah.asri@fai.umy.ac.id, safaah.restuning@fai.umy.ac.id
}

\begin{abstract}
Macroprudential Policy is a policy issued by Bank Indonesia to control systemic risk in the economy, both monetary risk and financial risk. This study aims to determine the effect of macroprudential factors, namely Gross Domestic Product, Inflation, and the BI Rate, on the market risk of Islamic Commercial Banks. The population in this study are Islamic Commercial Banks in Indonesia. The sampling method used was purposive sampling, and the samples in this study included Bank Syariah Mandiri, BNI Syariah, BRI Syariah, Mega Syariah, Panin Dubai Syariah, and Bank Muamalat with an observation period of 2015-2019. This research uses the panel data regression analysis method with Eviews software. The results showed that macroprudential factors had a significant effect on the market risk of Islamic banks. GDP has a positive effect on market risk, inflation has no effect on market risk, exchange rates have a negative effect on market risk, and the BI Rate has a positive effect on market risk.
\end{abstract}

Keywords: Macroprudential Policy, Market Risk, Islamic Banking, RAROC

\section{INTRODUCTION}

The macroprudential policy aims to minimize systemic risks to the economy, especially in the financial sector. This policy has been implemented since the 1998 crisis but is well known after the American crisis in 2008 [1]. The risks that are minimized in this policy include credit risk, liquidity risk and market risk. There are so many shocks from the macroeconomic segment that can shake Islamic banking. The product of macroprudential policy aims to minimize systemic risks that exist in the economy. Economic shocks also made the banking market experience turmoil, and people hadto think twice to engage in such activities. Seeing Destry Damayanti's expression as a Member of the LPS Board of Commissioners who said that the LDR / FDR of banking was $94 \%$ in 2018, which means this is in a vigilant level [2]. To reduce the FDR, this can be done when economic conditions are conducive.

The economic condition of a country cannot be separated from inflation. The inflation rate in Indonesia from November 2018 to April 2019 has been observed to fluctuate but has declined relatively. The lowest inflation was in March 2019 at $2.48 \%$, and the highest was in November 2018. Apart from inflation, it can be seen that the BI rate or the Bank Indonesia interest rate from November 2018 to April 2019 is constant with a value of $6.00 \%$. Based on data on the rupiah exchange rate against the dollar from November 2018 to April 2019 , it fluctuated with the highest exchange rate in December 2018 valued at 14,481 and the lowest in February 2019 at 14,042. The external factors mentioned above are one of the factors that can cause market risk. These factors are included in the Macroprudential Policy issued to control monetary policy. The movement of this macroprudential value can be a determining factor for Islamic Commercial Banks in running their business.

The level of inflation in a country must be maintained in a stable state. This is because inflation can have a negative impact on the condition of the Indonesian economy and dramatically affects people's behavior in relation to financial activities. The existence of high inflation will disrupt the function of money in society because money becomes less valuable, can weaken the spirit of the community to save because the need for cash is high, increase the tendency of spending, price games above the standard of ability and distribution of goods will be unstable [3]. Inflation can have an impact on the financial system in financial 
institutions, which must be mitigated in order to reduce possible losses. The existence of this inflation will also have an impact on liquidity, which reduces funding funds and decreases the level of returns on investments made in Islamic Banks.

The exchange rate or exchange rate is the price of a currency resulting from supply and demand in the foreign exchange market [4]. If the condition of the rupiah exchange rate weakens, it means that Indonesia's economic conditions are also sluggish, as well as if the rupiah strengthens, the economy will improve. This exchange rate affects the trade price because it sees the comparison of prices in the international world. With changes in fluctuating exchange rates, it can make people speculative about foreign currencies where if the rupiah exchange rate increases, many will flock to buy foreign currency and vice versa. When the rupiah exchange rate weakens, it will exchange their foreign currency so it will be very risky to the finance system. This fluctuating exchange rate condition will have an impact on the banking system. When the exchange rate strengthens, it will increase the return rate where the risk of this exchange rate can be suppressed and vice versa. If the exchange rate weakens, the return on investment will also decrease.

The interest rate (BI Rate) can affect the public's interest in investing their money in the bank or borrowing money from the bank. With the existence of the Bank Indonesia benchmark interest rate (BI Rate), it can be the basis for determining credit interest rates in conventional banking, and for Islamic banks, this is used to determine the profit-sharing ratio and margin in the financing process. When the BI Rate increases, there will be an increase in Islamic banks' competitiveness in determining the profit-sharing ratio. The phenomenonmayattract the public's desire to cooperate or finance Islamic banks. The BI Rate will also have an impact on the rate of return on these Islamic banks. If the BI Rate rises, it will increase market risk in Islamic banking, and if the BI Rate decreases, it can reduce the level of market risk in Islamic Banks.

Gross Domestic Product is a measure of a country's income that can provide an explanation of the production of goods and services within a certain time [5]. Data on the amount of Indonesia's GDP, which is relatively increasing and fluctuating, illustrates the condition of the country's economy. If a country has a high GDP value, it can be said that the country is in good condition and is experiencing progress. GDP will affect the distribution of financing from banking institutions, including Islamic Commercial Banks. GDP in high conditions will increase the amount of financing provided to the community and vice versa [6]. If the income earned by the community is good, the repayment rate (installments) by the community will also be good. When the community is able to return the funds obtained from financing, the bank will get a high return. Therefore, with a good GDP condition, it will increase the rate of return obtained from investing in Islamic banks and will reduce the risk of loss for Islamic banks.
When the economy improves, it can make banks provide uncontrolled financing and not think about risks in the future. This will grow the economy rapidly beyond what it should be in the short term. By looking at the relatively increasing number of NPF from 2018 to December 2019, this has an effect on the profitability of the banking business. Uncontrolled financing conditions and high NPF will create economic bubbles in the future. For this reason, macroprudential policies are needed to put a brake on activities that do not think about systemic risk. This macroprudential policy controls systemic risks and common shocks in an economy [1]. With the existence of macroprudential, it is hoped that it can assist banks in regulating the distribution of financing to the public and not creating high risks in the economy.

Many outside influences can make banks fail, such as risks to the ongoing business. This risk will always follow a business as long as the business lasts. Risk is an uncertain thing that can harm a business and reduce the level of profitability of the business [7]. Management of a Sharia Bank must be able to analyze the risks of its business activities so as not to harm the company. This risk can come from internal factors and company external factors, all of which can disrupt business activities. The existence of this risk threat is expected that the officeholders can pay attention to this and must be able to anticipate or mitigate. The management's anticipation can mitigate or withstand the risks that threaten the Islamic Banking business.

Islamic Commercial Banks have risks that are implied in each of their businesses. The risks faced by Islamic banks are more than conventional banks. Risks in Islamic banks include financing risk, liquidity risk, strategic risk, compliance risk, market risk, legal risk, investment risk, return risk, reputation risk, operational risk [7].

One of the risks that can occur in Islamic Commercial Banks is market risk. Market risk is a risk from external factors that can reduce the profitability of Islamic Commercial Banks. Many factors in market risk affect the state of Islamic Commercial Banks. Market risks that may occur include, among others, policies issued by the government or wrongful policymakers. The banking sector will think about how to get a return from the money distributed to the public and also how to return the funds invested by the customer to the bank. In the banking system, one way to measure returns is to use RaRoc (Risk-Adjusted Return on Capital) [8].

RAROC is used to measure returns in the banking system. Risks in investment must be mitigated so as not to cause losses to banks. Every bank must be able to manage risks that can threaten at any time that have an effect on the return on the investment. In RAROC, the level of profit and capital is adjusted according to the amount of risk so that it will provide about net profitability.

Sharia commercial banks, which are included in foreign exchange banks, are very concerned about market conditions since foreign exchange banks are related to foreign currency transactions. If you ignore 
market movements, it can cause the bank to experience losses. This foreign exchange bank serves transactions related to foreign currency values or the rupiah exchange rate. For this reason, the exchange rate may be related to market risk in Islamic Commercial Banks. Based on the above problems, this study will measure the influence of macroprudential policies on market risk in Islamic commercial banks classified as foreign exchange banks.

\section{2, LITERATURE REVIEW}

\subsection{Relevant Previous Research}

Islamic banks are always faced with various types of increasingly complex risks because banks have various businesses. The application of risk management can increase shareholder value and can provide an overview to managers about possible losses, with the existence of risk management in Islamic banks adjusted to the objectives, policies, size and complexity. For this reason, risk management in Islamic banks is essential. Every bank in Indonesia is required to implement effective risk management [9].

One of the most important parts of risk management is measuring risk. Several methods can be used to measure risk, includingRisk-Adjusted Return On Capital (RAROC). Research using the RAROC method is measure the risk of mudharabah deposit products. This study confirms that the mudharabah deposit product has a small risk when the RAROC value is high and has a high return on returns. Investing in mudharabah deposits is relatively safe because of the low risk. If the RAROC value is getting more positive and large, the risk management at the bank will be better. Other research adds that the more positive and immense RAROC value can reflect a bank's good activities [8].

In risk management, primarily on market risk, is closely related to the macro and economic conditions of a country. Several macro variables that can have an influence on market risk are inflation, interest rates, exchange rates, and so on. The variables of inflation risk, interest rate risk, and exchange rate risk do not affect the level of bank profitability [6]. The effect of macroprudential policies through CAR and GWM on the credit cycle can be seen from the macroprudential policy mechanism. CAR can counteract credit growth that is too high, and this can create systemic risk. On the other hand, the reserve requirement ratio can boost the bank intermediation function.However, it must be applied carefully since CAR and GWM can also be used to put the brakes on high credit growth rates [1].

To control macroeconomic conditions, Bank Indonesia has macroprudential policies that can affect the conditions of banking institutions. The macroprudential policies in the form of LTV (Loan to Value) wouldhave a positive impact on the performance of conventional banks and also contribute to responding to the risk of Islamic banks [10]. A differential effect of the macroprudential policy depending on the level of bank profitability.

\subsection{Macroprudential Policies and Market Risk for Islamic Banks}

Macroprudential policies have been applied in the world for a long time. This macroprudential is issued to minimize systemic risks that exist in the economy, especially the financial system of a country. According to the IMF, macroprudential policy is a policy that has the aim of maintaining overall financial system stability so as to minimize systemic risk [11]. Macroprudential policies emerged after the global crisis in 2008, stemming from over credit in the United States.[1] This bitter experience has had an impact on the economy and financial system and has provided lessons that the government must anticipate risks that occur in the financial sector, which have a vast impact.

Several macroprudential instruments include inflation. If the inflation that occurs in a country is high, it can be said that the country is unstable in its monetary system. Inflation has a fairly broad impact on economic stability. Inflation can influence investors to invest in Indonesia [12]. If inflation is high, many people take their savings from banks and will add to monetary instability. Inflation should be held in a stable and ideal condition, neither 0 nor high nor in a balanced condition.

Another macro instrument is the BI Rate. The BI Rate is the interest rate issued by Bank Indonesia as a monetary policy stance announced to the broader community [13]. The function and role of interest rates areto influence the price of an investment in international securities so that it will affect the demand and supply of foreign money. If the Indonesian BI Rate increases while foreign interest rates are relatively constant, it will affect Indonesian investors, namely reducing demand for dollars, and Indonesia's interest rates have competitive returns so that foreign investors will exchange foreign currency into rupiah currency. The increase in the BI Rate will encourage the strengthening of the rupiah currency. The monetary policy target will be reflected in developments in the Overnight Interbank money market interest rate $(\mathrm{PUAB} \mathrm{O} / \mathrm{N})$. With the movement of the PUAB, it is expected that the development of deposit rates and bank credit interest rates will be followed [14].

Another instrument related to macroprudential is the exchange rate. This exchange rate is the price of a country's currency against other countries [15]. The rupiah exchange rate is the price of the rupiah against foreign currencies. This exchange rate can change at any time, can go up, down, or be stable. This exchange rate is the most crucialfactor because it has a high influence on other macroeconomic variables.

Changes in the exchange rate can indicate a reflection of the economic conditions in a country. If a country's economy improves, the currency will tend to strengthen against foreign currencies. And vice versa, if the country's economic conditions decline, the exchange rate will tend to decline. A currency is said to be valuable if the demand for that currency is more than the supply of that money. Adversely, if the demanded money quantity is lower than the supply, its value will decrease. 
Another macroprudential instrument is the Gross Domestic Product (GDP). GDP is the value of goods and services from production in a country in a certain period. GDP is calculated by summing the output of Indonesian citizens plus foreign nationals working in Indonesia. The benefit of calculating GDP is that it can analyze the level of welfare and prosperity of the community and calculate the productivity of a country.[16] The method that is usually used to calculate GDP is the expenditure method with the following formula:

$$
G D P=C+I+G+(x-m)
$$

Some of the macroprudential instruments mentioned above will affect the condition of the Indonesian economy, which will have an impact on financial institutions, especially banks. In banking institutions, there are risks related to macroeconomic conditions known as market risks. It results from changes in market conditions that externally reduce the level of profitability or gain losses from a business [17]. This risk will always be inherent in the business activities of risk banking institutions that can be caused by market changes in business lines.

In Islamic banks, market risk is unique due to the characteristics of the contract. Not only due to transactions in the financial market, such as investing in the stock market and sukuk, but the market risk in Islamic banks can occur from asset and liability management activities outside of transaction activities. Activities that can potentially cause market risk include financing activities through the Murabahah contract, ijarah muntahiya bittamlik and istishna' [18]. The phenomenaoccur due to differences in asset prices after being acquired by the bank and before being handed over to the debtor in the Murabahah, Ijarah and Istishna'contracts. Changes in the price of the assets returned by the debtor can be caused by defective goods or the contract period is shorter than the useful life of the asset. Price movements before and after delivery of goods by the seller occur during the salam contract.

This method is used to calculate the trade-off between risk and return on assets and investments. The existence of the RAROC measurement can have benefits, namely: (a) Calculation in the allocation of capital to be reserved as a form of risk mitigation; (b) calculating the level of performance by considering the risk aspects faced. Islamic banks can use RAROC to determine the level of margin desired according to their respective financing instruments. The RAROC calculation is as follows:

$$
\begin{array}{r}
\text { RaRoc } \\
=\frac{R A R}{R C}
\end{array}
$$

Where:

$$
\begin{aligned}
& R A R=T R-T C-E L \\
& R C=W L-E L \\
& W L=E L+\frac{Z c \cdot \sigma}{\sqrt{N}} \\
& \text { Explanation: } \\
& \text { RAR= Rist Adjusted Return } \\
& \mathrm{RC}=\text { Risk Capital }
\end{aligned}
$$

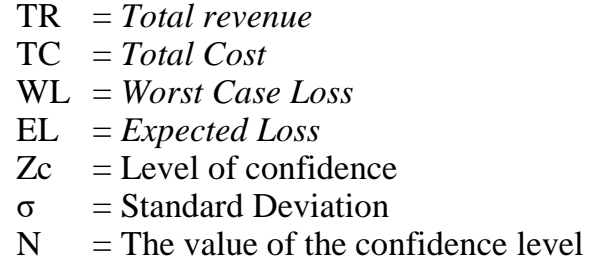

\subsection{Research Hypothesis}

The hypothesis proposed in this study is:

1. $\mathrm{H}_{0}=$ The level of GDP, Inflation, Exchange Rate and BI Rate do not have a negative effect on Market Risk in Islamic Commercial Banks.

$\mathrm{H}_{1} \quad=$ The level of GDP, Inflation, Exchange Rate and BI Rate do not have a negative effect on Market Risk in Islamic Commercial Banks.

2. $\mathrm{H}_{0}=$ The level of GDP does not have a negative effect on Market Risk in Islamic Commercial Banks.

$\mathrm{H}_{1} \quad=$ The GDP level has a significant negative effect on Market Risk in Islamic Commercial Banks.

3. $\mathrm{H}_{0}=$ Inflation rate does not have a negative effect on Market Risk in Islamic Commercial Banks.

$\mathrm{H}_{1} \quad=$ Inflation rate has a significant negative effect on Market Risk in Islamic Commercial Banks.

4. $\mathrm{H}_{0}=$ The Exchange Rate Rate has no negative effect on Market Risk in Islamic Commercial Banks.

$\mathrm{H}_{1} \quad=$ Exchange Rate Rate has a significant negative effect on Market Risk in Islamic Commercial Banks.

5. $\mathrm{H}_{0}=$ The BI Rate level does not have a positive-negative effect on Market Risk in Islamic Commercial Banks.

$\mathrm{H}_{1} \quad=$ The BI Rate level has a significant positive effect on Market Risk in Islamic Commercial Banks.

\section{RESEARCH METHODOLOGY}

This type of research is quantitative-explanative research. Explanatory research is a research method used to explain the relationship, difference, the influence of one or more variables with other variables [19].

\subsection{Population and Sample}

The population in this study were 14 Islamic commercial banks from the Financial Services Authority (OJK) data. The sample selection in this study using the purposive sampling technique. Where the criteria used are included in Foreign Exchange Sharia Commercial Banks, providing quarterly data, and publishing financial reports on the website of the related bank or the website of the Financial Services Authority (OJK).

Based on the above criteria, the samples taken were six Islamic Foreign Exchange Commercial Banks. According to the Financial Services Authority report, there are six sharia commercial banks that have provided financial reports for 2015-2019. The six banks are Bank 
Syariah Mandiri, BNI Syariah, BRI Syariah, Bank Mega Syariah, Bank Panin Dubai Syariah, and Bank Muamalat.

\subsection{Data Analysis Techniques}

This study uses panel data regression analysis with E-views version 9. Panel data is a combination of time series data and cross-section data. The advantage of panel data is that it will produce a high degree of freedom. The linear regression model using panel data for this study is as follows:

$$
\begin{aligned}
& Y=\alpha+b X 1 i t+b 2 X 2 i t+b 3 X 3 i t+b 4 X 4 i t+e \\
& \text { Explanation: } \\
& \mathrm{Y}=\text { RAROC } \\
& \alpha=\text { Constant } \\
& \mathrm{X}_{1}=\text { GDP } \\
& \mathrm{X}_{2}=\text { Inflation } \\
& \mathrm{X}_{3}=\text { Exchange Rate } \\
& \mathrm{X}_{4}=\text { BI Rate } \\
& \mathrm{b}_{(1, ., 2)}=\text { independent variable regression coefficient } \\
& \mathrm{e}=\text { error term } \\
& \mathrm{t}=\text { time } \\
& \mathrm{i}=\text { company }
\end{aligned}
$$

The hypothesis testing technique in this study uses several analyzes, namely: Coefficient of Determination (R2), Simultaneous Significance Test (F Statistical Test), and t-test (t-test).

\section{ANALYSIS AND DISCUSSION}

Financial business is an activity that deals with risk and returns. Sharia Commercial Bank is one of the businesses in the financial business segment. Islamic banks face various kinds of risks and must be mitigated so as not to cause huge losses. Some of the risks faced include financing risk, liquidity risk, market risk and capital risk. Especially for market risk, it is closely related to macro-financial conditions. In addition, the macro condition of a country is related to the macroprudential policies applied to that country.

\subsection{Hypothesis Test Results}

Hypothesis testing uses the $\mathrm{t}$ statistical test or known as the t-test, to find out how much influence the independent variable alone or partially can influence the dependent variable.

Table 1. T-Test

\begin{tabular}{ccc} 
Variable & Coefficient & Prob. \\
\hline \hline C & -3199118. & 0.4119 \\
PDB? & 7.230813 & 0.0000 \\
INF? & -172872.8 & 0.2122 \\
NIT? & -1187.873 & 0.0066 \\
BIR? & 577112.3 & 0.0013 \\
\hline
\end{tabular}

Source:Output of Eviews version 9

1) Variable Gross Domestic Product

From the test results, the Gross Domestic Product (X1) variable has a positive regression coefficient of 7.230813 with a significance level of 0.000. Thus, the Gross Domestic Product variable has a significant positive effect on the market risk of
Islamic Commercial Banks as measured by RAROC. The hypothesis H1 in this study means it is rejected.

2) Variable Inflation

From the test results, the inflation variable (X2) has a regression coefficient of -172872.8 with a significance level of 0.2122 . Thus, the inflation variable has an insignificant negative effect on the market risk as measured by RAROC. The hypothesis $\mathrm{H} 1$ in this study means it is rejected.

3) VariableExchange Rate

From the test results, the exchange rate variable (X3) has a regression coefficient of $-1187,873$ with a significance level of 0.0066 . Thus, the exchange rate variable has a significant adverse effect on the market risk measured by RAROC. The hypothesis $\mathrm{H} 1$ in this study means it is accepted.

4) Variable BI Rate

From the test results, the BI Rate (X4) variable has a regression coefficient of 577112.3 with a significance level of 0.0013 . Thus, the BI Rate variable has a significant positive effect on the market risk as measured by RAROC. The hypothesis $\mathrm{H} 1$ in this study means it is accepted.

\subsection{Macroprudential Effect on Market Risk}

\subsubsection{The Effect of Gross Domestic Product (GDP) on Market Risk for Islamic Commercial Banks}

In the measurements carried out, the results show that the Gross Domestic Product has a positive effect on market risk in Islamic Commercial Banks. The significance value of the Gross Domestic Product is 0.000 , which means that it has a significant effect on market risk in Islamic Commercial Banks. The direction of the influence of this Gross Domestic Product is positive amounting to 7.230813. This means that if the Gross Domestic Product increases, the market risk for Islamic Commercial Banks will also increase.

This is not in accordance with the hypothesis in the study, which states that if GDP increases, it will reduce the market risk of Islamic Commercial Banks. Based on the existing theory, when GDP is in an increasing condition or in its best performance, it will reduce the risk to Islamic banks because the average income of the community has increased. This is because of the average income earned by the community increases

The assumption is that the return of financing funds from the community will not experience difficulties because of an increase in community income. The bank will get the profit as targeted so as to increase the expected return on investment. However, the results of this test show that the correlation between GDP and market risk is positive, so there are other factors that cause when GDP conditions increase and also increase the existing market risk. If GDP increases, the market risk will also increase.

Market risk is a systemic risk that is not only in the short term. This systemic effect will have an impact in 
the long term. If this systemic effect is ignored or ignored by banking institutions, it will cause a very high economic bubble. The value of the Gross Domestic Product (GDP) from year to year is not always in good condition. There are several internal factors that can cause a high risk in the future. Banking institutions channel funds massively when economic conditions improve, marked by high Gross Domestic Product value, but the risks that arise are also high. This is in accordance with Baroroh's research that in the long term, when the economy has increased by looking at the increase in GDP, it can be seen that the NPF value has also increased due to indications of moral hazard in Islamic banking [20].

If the Islamic Commercial Bank takes the opportunity to meet the financing target when the economic conditions are good, then this can cause unpredictable future risks. The calculation of the distribution of financing is carried out by banks using the DBR/DSR calculation for the last three months. The condition of GDP in the last threemonths has not experienced a sharp fluctuation so that if the economic condition is in shock, the financing that was initially safe and the condition of the ability to pay is also safe, and it could pose a risk to the bank.

If the country's economic conditions are in chaos, it will make many people experience default and will reduce the level of profit at the Islamic bank. This profit should be an additional income for the bank when conditions are chaotic due to carelessness in providing financing without thinking about systemic risk in the future. Another internal factor comes from marketing in distributing funds to customers who do not have a high prudence level and only think about achieving targets. This activity can be done by manipulating the data of customers who want to apply for financing to Islamic commercial banks to be funded. As a result,it ignores the prudential aspect of distributing funds to the public. Distribution of funds to the public is a form of bank investment to customers in financing.

\subsubsection{The Effect of Inflation on Market Risk for Islamic Commercial Banks}

The results of testing the inflation variable on RAROC in Islamic Commercial Banks show that inflation does not affect market risk in Islamic Banks. The significance value of the inflation variable is 0.2122 , which means that it does not have a significant effect on market risk in Islamic commercial banks. The direction of the influence of inflation is negative at 172872.8. However, the significance test results are more than 0.05 , which means that it is not significant or has no significant effect on the risk of Islamic commercial banks.

Inflation means that although the inflation fluctuates with various economic conditions, there is no serious shock to the market risk for Islamic Commercial Banks. This is in line with Baroroh's research [20], which states that inflation has no effect on Islamic banks because the model owned by Islamic banks is a profit and risksharing model. This means that Islamic banks are not affected by fluctuating inflation. In addition, the inflation rate in Indonesia is still stable and controlled by the government. Based on the conditions of inflation in a good economy, volatile food and administrative prices can be controlled by the government so that in the short term, inflation does not affect Islamic Commercial Banks. Inflation conditions that do not affect public activities mean that inflation also does not affect market risk in Islamic banks.

The condition of fluctuating inflation does not make people windowless in paying their obligations to Islamic banks. This obligation is repayment of financing installments made by the public to the bank. The smooth rate of return of the public on their obligations will enable banks to maintain liquidity and maintain profitability levels to match expectations. Islamic Commercial Banks in returning funds to the public (customers) there are no obstacles and can be in accordance with the expectations of people who invest in Islamic banks.

\subsubsection{The Effect of Exchange Rate on Market Risk for Islamic Commercial Banks}

The test results of the exchange rate variable or exchange rate have a negative effect on market risk in Islamic Commercial Banks. The significance value of the exchange rate is 0.0066 , which means that it has a very significant negative effect on market risk in Islamic Commercial Banks. The direction of the influence of the exchange rate is negative at $-1187,873$, which means that if the exchange rate strengthens, the market risk in Islamic Commercial Banks will decrease. In this case, if the rupiah strengthens by 1 point, it will reduce market risk in Islamic Commercial Banks by 1187,873 .

If the exchange rate strengthens, it will reduce the level of risk, especially market risk. This is in line with research by Najiatun, which states that the exchange rate will have a negative effect on the NPF of banks [21]. Therefore, Foreign Exchange Sharia Commercial Banks must pay attention to exchange rates in foreign exchange activities. With uncertain foreign exchange movements, there are many risks in the business related to foreign exchange, be it buying and selling foreign currency or foreign currency deposits in Islamic banks.

Foreign exchange Islamic banks are banks that provide products and services related to foreign exchange. Also, many Islamic banks channel financing for business activities originating from abroad (imports). In connection with the financing made for the import goods business sector, if the rupiah weakens, it will cause a decrease the quality of payments by entrepreneurs involved in the business (importers). This is because customer payments to overseas suppliers use foreign currency. When the rupiah exchange rate weakens, the amount of rupiah needed will be more to pay for these transactions, which has the potential to reduce the level of customer collectability in paying obligations to the bank. Therefore, it can be said that the exchange rate has a negative effect on market risk. When the exchange rate strengthens, it will reduce market risk, and vice versa. If the exchange rate 
weakens, it will increase the market risk for Islamic Foreign Exchange Commercial Banks.

The strengthening of the exchange rate is used as an indicator of the rupiah's price so that people who are financed by Islamic Banks engaged in international business will make normal installment payments. This is because the business owned by the entrepreneur is in good condition, so that the payment of obligations to the bank is not a problem. The smooth condition of these customers allowed the banks to get the profit they expected from the transaction. This profit will enable banks to provide high returns to the public (customers) who save or invest their funds in Islamic Commercial Banks.

\subsubsection{The Effect of BI Rate on Market Risk for Islamic Commercial Banks}

The results of the BI Rate variable test have a positive effect on market risk in Islamic Commercial Banks. The significance value of the BI Rate variable is 0.0013 , which means that it has a significant effect on the market risk of Islamic Commercial Banks. The direction of the influence of the BI Rate is at a positive value of 577112.3. This means that if the BI Rate increases, the market risk for Islamic Commercial Banks will also increase. Every 1 point increase in the BI Rate value will increase market risk by 577112.3 . This is a big effect of the BI Rate on the market risk of Islamic Commercial Banks.

The BI Rate affects many sectors. The BI Rate is a policy to regulate the amount of money circulating in society. The BI Rate has a positive influence on the market risk of Islamic banks, which is in line with the results of research by Syah, which states that an increase in the BI Rate will reduce ROA [22]. Profitability relates to market risk in Islamic banks. Market risk mitigation aims to reduce or minimize losses arising from banking activities themselves.

When economic conditions experience contraction, the government tightens the BI Rate by increasing the BI Rate. The policy of raising the BI Rate aims to attract the amount of money in circulation. The increase in the BI Rate will cause conventional bank interest rates also to increase. This makes people move their money from Islamic banks to conventional banks. Besides, it also affects people who prefer to save rather than consume. The attitude of the people who choose to save their money will have an effect on the real industrial sector. A decrease in purchases will affect the turnover of entrepreneurs. A decrease in turnover will have an impact on decreasing the collectability of borrowing customers, which can cause losses for the bank.

A high BI Rate indicates that the economy is not well. Bank Indonesia will withdraw the amount of money in circulation. These activities will have an impact on decreasing business turnover in community business units. The decline in turnover will make business units potentially unable to pay installments to Islamic banks. This situation could potentially reduce the collectability of these customers. The large number of customers who cannot pay their obligations will have an impact on low bank profits. This has the potential to reduce the level of returns to people who invest in Islamic Banks. In fact, the higher the turnover of funds from the community, the higher the level of returns that will be obtained.

\section{CONCLUSION}

Gross Domestic Product has no adverse effect on market risk. However, it has a positive influence on Islamic Commercial Bank Market Risk. The increase in GDP will also increase the systemic market risk in the future. This study found that the higher the GDP, the higher the market risk in Islamic Commercial Banks due to moral hazard factors from one of the parties.

Inflation does not have a significant effect on market risk for Islamic commercial banks. In conditions of fluctuating inflation, the government can overcome it by controlling the inflation conditions in Indonesia to remain stable both on volatile food and administrativestressed prices. The exchange rate has a negative influence on the market risk of Islamic commercial banks. If the exchange rate strengthens, the economy is in good condition and will reduce the risk of default on customer payments. The BI rate has a significant positive effect on market risk for Islamic commercial banks. The impact is positive so that if the BI rate is raised, the market risk in Islamic commercial banks will also increase.

The findings in this study are in line with the research of Syah which uses the inflation variable and the BI Rate [22]. This study adds a new point that has not been used by previous researchers, namely linking the market risk of Islamic banks with macroeconomic conditions in Indonesia. This is something new, because very few previous studies have examined macroprudential with market risk, especially in Islamic financial institutions.

\section{REFERENCES}

[1] E. M. T. Yoel, "Pengaruh Kebijakan Makroprudensial Terhadap Siklus Kredit: Sebuah Studi Penggunaan Instrumen CAR dan GWM Perbankan Indonesia 2006-2013," J. Bina Ekon., vol. 20, no. 1, pp. 77-96, 2016.

[2] R. Franedya, "Likuiditas Ketat, LPS: Dana Menumpuk di Bank Besar," CNBC Indonesia, 2018 [Online]. Available: https://www.cnbcindonesia.com/market/201812041 11629-17-44873/likuiditas-ketat-lps-danamenumpuk-di-bank-besar.

[3] Boediono, Ekonomi Moneter, 3rd ed. Yogyakarta: BPFE UGM, 2014.

[4] S. Raharjo, "Pengaruh Inflasi, Nilai Kurs Rupiah, Dan Tingkat Suku Bunga Terhadap Harga Saham Di Bursa Efek Indonesia," J. ProBank, vol. 1, no. 3, 2010. 
[5] B. P. Statistik, "Produk Domestik Bruto," 2020. [Online]. Available: https://www.bps.go.id/subject/11/produk-domestikbruto--lapangan-usaha-.html.

[6] N. Shenni and P. A. Darmawan, "Pengaruh Pertumbuhan Produk Domestik Bruto dan Inflasi Terhadap Non Performing Finance Bank Syariah," J. Adm. Bisnis, vol. 61, no. 2, pp. 168-178, 2018.

[7] N. Hidayati, “Analisis Risiko Terhadap Profitabilitas Bank Umum Syariah di Indonesia," UIN Sunan Kalijaga, 2018.

[8] A. Ridiawati, "Aplikasi Metode VAR dan RAROC atas Risiko dan Pengembalian Hasil pada Bank Syariah Mandiri," J. Ilm. Ris. Akunt., vol. 7, no. 03, pp. 124-137, 2018.

[9] Rusdan, "Urgensi Manajemen Pengawasan Risiko Bank Syariah," Palapa J. Stud. Keislam. dan Ilmu Pendidik., vol. 4, no. 2, pp. 85-103, 2016.

[10] Fadili, Zainuri, and T. H. Priyono, "Analisis RiskTaking Behavior Sektor Perbankan dalam Merespon Bauran Kebijakan Bank Indonesia," in Prosiding Seminar Nasional Manajemen dan Bisnis ke-3, 2018, pp. 559-571.

[11] V. Maulina, “Assesment Efektifitas Instrumen Makroprudensial dalam Mengurangi Risiko Kredit," in Seminar Nasional \& Call For Paper, FEB Unikama, 2017, pp. 422-432.

[12] S. T. Widodo, Ekonomi Indonesia. Yogyakarta: Kanisius, 1997.

[13] Bank Indonesia, "Laporan Kebijakan Moneter Ekonomi, Moneter, Keuangan,” 2019.
[14] S. Puspopranoto, Keuangan Perbankan dan Pasar Keuangan, Konsep, Teori, dan Realitas. Jakarta: LP3ES, 2004.

[15] N. G. Mankiw, Makroekonomi. Jakarta: Airlangga, 2007.

[16] D. Meyliana and A. S. Mulazid, "Pengaruh Produk Domestik Bruto (PDB), Jumlah Bagi Hasil dan Jumlah Kantor terhadap Jumlah Deposito Mudharabah Bank Syariah di Indonesia Periode 2011-2015," Econ. J. Ekon. Islam, vol. 8, no. 2, pp. 263-284, 2017.

[17] A. A. Karim, Bank Syariah: Analisis Fiqih dan Keuangan. Jakarta: Raja Grafindo Persada, 2008.

[18]B. R. Rustam, Manajemen Risiko Perbankan Syariah di Indonesia. Jakarta: Salemba Empat, 2013.

[19] B. Bungin, Analisis Data Penelitian Kualitatif. Jakarta: Raja Grafindo Persada, 2006.

[20]H. Baroroh, "Kinerja Pembiayaan Perbankan Syariah: Indikasi Moral Hazard," Al-Mal J. Akunt. dan Keuang. Islam, vol. 1, no. 1, pp. 39-60, 2020.

[21] Najiatun, M. Sanusi, M. Rahman, and S. Herianingrum, "Analisis Variabel Makroekonomi Terhadap NPF Perbankan Syariah di Indonesia," J Ekon., vol. 24, no. 3, pp. 335-349, 2019.

[22] T. A. Syah, "Pengaruh Inflasi, BI RAte, NPF, Dan BOPO Terhadap Profitabilitas Bank Umum Syariah Di Indonesia," el-Jizya J. Ekon. Islam, vol. 6, no. 1, pp. 133-153, 2018. 